\title{
Residence Hall Libraries and Their Educational Potential
}

\begin{abstract}
Over the years the library press has consistently emphasized the importance of adequate support standards for residence hall libraries, but the requisite support levels have not always been maintained. A survey of institutional experience with such libraries indicates that they seldom succeed without adequate funding and continuing administrative oversight from the institutional library system. Cases are cited, and reservations as to their value are proposed. Needed research is identified, and guidelines for their establishment are suggested.
\end{abstract}

$T_{1}$ HOSE INVOLVED in higher education today or who are familiar with the problems arising from rapidly burgeoning student populations in colleges and universities are aware of the tremendous interest and concern that is being widely felt with respect to the role and function of student housing. In past years universities and colleges generally felt little responsibility for providing residence halls with facilities beyond those required to furnish shelter and meals for students. Today, there is increasing interest in experimenting with new types of campus housing that will contribute directly to the intellectual, cultural, and social development of students during their college years. New awareness of the educational potential of residence hall libraries is indicative of growing interest in creating in student living quar-

Dr. Stanford is Director of Libraries in the University of Minnesota. This paper was presented on April 2, 1968 in Minneapolis, Minnesota, at the annual conference of the National Association of Student Personnel Administrators. ters facilities where enriched learning experiences, as well as rooms for sleeping and eating, are provided.

Writing on this subject in 1958 Dean E. G. Williamson of Minnesota, in an article entitled, "Students' Residences: Shelter or Education?" mentioned dormitory libraries, but warned that they must have substance if they are to be effective. He said,

We need to perceive clearly that it is not a sufficient intellectual program to possess a library of discarded mystery stories and old novels as stimulants of things intellectual. Rather should the residence library be stocked with basic reference books, at least to the extent of a good encyclopedia. And those who provide leadership in the dormitory management, upperclassmen, and graduate counselors, would also be committed and reasonably skilled in using informal and casual relationships of the lounge, the library, the dining hall, and the private room to feed intellectual content into what otherwise may well be vacuous conversation. ${ }^{1}$

\footnotetext{
${ }^{1}$ E. G. Williamson, 'Students' Residences: Shelter or Education?" Personnel and Guidance Journal, XXXVI (February 1958), 396-97.
} 
Responses elicited by the present author from various colleagues, describing residence hall library programs in their respective institutions, indicate that the validity of Dean Williamson's comment is clearly supported by experience.

If the provision of library collections in student housing facilities is to be educationally meaningful, such efforts require careful planning, continuity of supervision and administration, and a substantial commitment in funds on a recurring basis. The experience among the institutions from which recent information has been received suggests that too frequently dormitory collections have been established when one or two individuals with great enthusiasm have been willing to spearhead an initial effort which, unless sustained by others in subsequent years, has soon led to disillusionment, as losses have depleted original holdings and the remaining books and broken files of magazines have fallen into disuse. Residence hall libraries have survived and prospered only where continuing and specifically assigned responsibility for the on-going management and enrichment of collections has been provided.

\section{Objectives and Goals}

Since the House Plan at Harvard, made possible in 1928 through the generosity of Mr. Edward S. Harkness, represents one of the first significant efforts to develop residence hall libraries in an American university, the rationale of this plan is worthy of mention. The idea behind the Harvard system was to integrate the work of tutors and students, under the guidance of resident "Masters," to make these houses genuine living and learning centers and "to breathe new life into the instructional methods of Harvard College through the very channel which was to restore to undergraduate life some of the social values it had offered before the college became merely one unit in a great university." 2

In order to provide the facilities for implementing this goal, each house was designed with spacious, comfortable, and attractive library quarters, and the book collections were selected by the Master of each house, to serve a wide diversity of undergraduate reading interests. In the case of Lowell House the goal was to create "a scholarly gentlemen's library to appeal to literary tastes and to encourage potential bibliophiles." 3 Gradually some differences in emphasis developed among the various Harvard houses, with one stressing more materials in the humanities, while others leaned more heavily toward the sciences. When, in 1930, conservative critics questioned the need for the outlay these libraries represented, in a university already so richly equipped for academic pursuits, one alumnus defended the enterprise in the following eloquent response, "It is in the hope of contriving an intellectual climate ever more friendly to that mysterious ferment which here and there causes to rise in some human breast the yeast of a creative life purpose." 4 Another apologist wrote, "The books they contain may be seen not as tools with which instructors teach men a few things, but as windows through which students may discover many things."5

More recently Nevitt Sanford wrote, in urging enriched concept of student housing, "We must find ways to bring the intellectual life of the college into the establishments where students live. We must create campus-wide studentfaculty or faculty-student communities in which the social need of students, far

\footnotetext{
${ }^{2}$ Frank N. Jones, "The Libraries of the Harvard Houses," Harvard Library Bulletin, II (Autumn 1948), 362.

${ }^{3}$ Ibid., 363.

4 Ibid., 371

${ }^{5}$ Ibid.
} 
from being suppressed, are brought into the service of the intellectual aims of the college."6

In 1940 Harvie Branscomb, in his volume Teaching With Books, urged that dormitory facilities make provision for library materials to enrich the educational opportunities of resident students. The theory back of dormitory collections, he wrote, is "that a student will pick up a book in the lounge and browse for fifteen minutes or half an hour, when she would not bother to go to the library for a book." Once interested, through such browsing, he indicated, the book would then be taken into one's room and completed. ${ }^{7}$

\section{The Problem of Scope}

The provision of libraries in student living facilities can serve a variety of functions, and in order to be successful the purposes and objectives of such collections must be well defined in advance. Should dormitory libraries be purely recreational? Should they comprise primarily "great books" or "world classics" in various subject fields? Should they stress popular "escape" reading? Should they focus on "best sellers?" Should they include journals of some academic substance, or should they provide primarily popular magazines and newspapers for leisure reading? Or should they perhaps emphasize a "well-rounded" collection of good books in all subject fields-or should they attempt to reflect the "gentlemen's library" concept? Finally, should they stress or include required or optional course-related books to provide more convenient access to assigned readings that otherwise would have to

- Nevitt Sanford, "Ends and Means in Higher Education," Current Issues in Higher Education, 1962 in "Higher Education in an Age of Revolutions" (Association for Higher Education: Proceedings of the Seventeenth Annual Conference on Higher Education). p. 19.

Ibid. be obtained from the "reserve room" in the general library? Should dormitory collections emphasize hard-bound titles, presumably of enduring value, or should they liberally provide paperbacks that ought possibly to be considered expendable? These are some of the questions that need to be thought through in determining what role residence hall libraries should try to fulfill in a given campus situation. And they should be squarely faced before substantial funds are committed to the building of such collections.

The scope of the collections comprising the University of Indiana dormitory library plan suggests the educational potential they are designed there to serve. Their purpose, writes the librarian is,

To have a well balanced collection of both recreational and study materials, but perforce the ever rising enrollment we are experiencing increases the student load of our residence hall libraries. Emphasis on browsing with a good art book or an illustrated book on a foreign country, reading a current magazine, or listening to a good recording remains an important factor in selecting materials for these libraries; for what serves to broaden horizons outside the classroom is always a rich reward to the student who uses his residence hall library.

Dr. Branscomb, cited above, noted that not all dormitory libraries have been successful, and he emphasized the necessity for collections sufficiently large to reward repeated browsing and the need for continual enrichment of initial collections through well-selected additions of new titles. One device he proposed for the accomplishment of such enrichment was the rotation or interchange of books among different dormitories, a practice that some institutions are following successfully today. He criticized the lack of basic reference tools that seemed to characterize most 
residence hall libraries he had seen. On the educational implications of such collections, Dr. Branscomb suggested that to build up the habit of turning to library sources for information and to clarify various historical facts is an educational contribution of the first rank. If dormitory collections are worth doing at all, he asserted, the first object of attention should be a carefully selected set of reference tools.

A mere few hundred volumes are not sufficient to make any significant impact on students' educational experiences. The likelihood of finding a needed book in a collection of only a thousand volumes is rather small. To have any real educational potential, a residence hall library must have a basic reference collection, a good selection of periodicals, and total holdings of at least several thousand volumes. Institutions interested in developing basic reference collections for residence hall libraries will find the list of ninety-six such titles compiled in 1966 by Pennsylvania State University useful. At retail prices this proposed collection would cost approximately $\$ 1,500$. More recently Penn State issued a more modest list representing the thirty-one most used titles from its basic list. The cost of this more selective collection would come within $\$ 400$.

\section{Currently Operating Residence Hall Libraries}

Let us now turn to the status of residence hall libraries today. Where are such undertakings now operating successfully, and what are the characteristics of such libraries? From the correspondence received it appears that Michigan State, with libraries in its "living-learning units," Southern Illinois University, the University of Indiana, UCLA, University of Illinois, and Syracuse University, each with several dormitory libraries, are among those that apparently have successful programs. Similarly, Princeton University, with its
Julian Street Library, seems to have a viable and successful operation; and Pennsylvania State University has recently launched the first of a series of similar collections. The house libraries at Harvard, now with sizable collections of considerable breadth, should also be included in this group.

In recent years, as Michigan State has constructed enormous residence hall complexes at some distance from the university's main library, it has developed a strong and growing program of satellite libraries, each serving the residents in a cluster of high-rise dormitory buildings. Indiana and UCLA likewise have active, well-organized systems of such libraries, coordinated and staffed under the direction of the university library administration. UCLA provides a computer-based list of suggested titles for these collections, complete with catalog entries, call numbers, and price information, for the guidance of students who, in each dormitory, recommend titles to be purchased for their library. The university library also maintains an updated magnetic tape printed catalog of each library, and a Union Catalog of the holdings of all residence hall libraries, showing the location of specific titles.

\section{Characteristics of Successful Programs}

It appears from the experience of these institutions that certain basic characteristics have been common to the effectiveness and success of their programs. In each case the continuity of development, guidance, and staffing has centered in the university library. And in each case regular hours of opening and service have been maintained. In institutions where the entire effort has been dependent on volunteer help, residence hall libraries have usually failed or fallen into decline in a relatively short time. It appears that when such an undertaking is left by default as everyone's 
responsibility, it becomes no one's responsibility, and withers on the vine. For success, therefore, dormitory libraries require continual attention and help from the library administration.

A second element essential to a successful residence hall library program is the active support and personal involvement of students and faculty members. This is achieved often through studentfaculty advisory committees and through patron participation in selecting and recommending holdings, as is the practice at UCLA.

\section{Financial Support}

A third element, and one that should be taken into account before an institution embarks on a program of residence hall libraries, is the need to provide regular and relatively substantial funding for such libraries-not simply to cover the initial cost of buying books and placing them in a dormitory reading room or lounge. Since the level of funding required for a successful program can represent a significant element in overall library support, and therefore must be weighed in relation to other library needs, the maintenance of separate residence hall libraries involves an on-going commitment both by the library and the university administration, and therefore represents a basic decision of overall institutional policy. In 1962 Princeton University reported, for its one residence hall library, an initial cost of $\$ 30,000$ plus an expected $\$ 5,000$ a year for development. Indiana, supporting ten such libraries with total holdings of over 36,000 volumes, reports a budget of $\$ 40,000$ for these units, while UCLA, with five dormitory libraries, devotes over $\$ 30,000$ a year to their operation.

\section{Factors Affecting UsE}

The evidence concerning the use of residence hall libraries varies widely among institutions. Some report a great deal of use, particularly where courserelated materials are heavily represented. Others suggest that while the use appears to be heavy, much of it seems to be of a study-hall nature, with minimal use of the collection. Very little information is available on the kinds and amount of reading that takes place in these libraries. Most of them maintain only afternoon and/or evening hours, and their success in some cases seems to relate both to hours of opening and to the distance of the dormitory complex, with a high concentration of resident students, from the main campus library.

In a study of its several dormitory libraries undertaken at Syracuse University during a sample period last year, the use of various libraries exclusively for study (with no use of the collection) ranged from 36 per cent to 70 per cent. The use of these libraries for reference and browsing ranged from 20 per cent in one unit to 46 per cent in another. Possibly it is significant that the library most used for reference work was a dormitory for freshmen, and the library most used as a general study hall was in a mixed residence serving all four undergraduate classes. While these data are only indicative and cannot be considered conclusive, they seem to confirm the impression reflected in responses from other institutions that the use of residence hall libraries is more heavily oriented toward the study-hall function than toward use of the collections, except where course-related materials, otherwise requiring a trip to the main library, were represented in the dormitory collections.

\section{Expressions of DouBT}

Not all of the responses received from college and university librarians favored the development and maintenance of residence hall libraries. On the negative 
side letters were received from several librarians who, after having tried such programs, had become disillusioned. In such cases it generally appeared that their collections were either minimal to begin with or had not been kept up, or that the responsibility for the enterprise had depended largely on individual volunteers, with little continuity. Several respondents noted that book losses resulting from lack of regular staffing and supervision had led to general apathy on the part of all concerned.

One such librarian in a small midwestern college, after enthusiastically starting a dormitory library program some years ago, stated, "Without regular staffing these were all looted and scattered indiscriminately . . . especially in the men's dorm the collection simply melted away. My conclusions are that unless these are set up as staffed and controlled collections . . . it is not worth investing money in them ... or expecting much of them.... The great prevalence of paperbacks since 1958 has taken considerable pressure off of this kind of dormitory use."

Another college librarian, from New England, wrote, after telling of an experiment that dwindled after the original faculty dormitory resident left the campus, "I question now whether, in a highly centralized campus where few students need to walk more than a block to the main library's browsing collection, the educational advantages could ever justify the expense of selection, processing, and supervision which the library would have to assume" to maintain dormitory libraries.

Still another respondent, from a major university where dormitory libraries were enthusiastically established and later abandoned, feels that a house collection would have to be quite large to be really useful, and that the creation of such large units would dilute the library's resources without solving the problem of book access. He believes, however, that a well-selected reference collection in each house would serve a real need, but that its cost should not be borne by the university library. $\mathrm{He}$ concluded that although no one can deny that residence hall libraries have educational potential, only a very small handful of students make use of that potential. The reason, he says, is that, as reading studies showed twenty-five years ago, "Most students read little beyond what is required by their course work." These, then, are typical of the negative responses received.

Most librarians would doubtless like to feel that they personally, by providing conveniently accessible and enriched collections, could somehow stimulate students to read, on their own initiative, beyond the requirements of their course assignments. They recognize as competition for student time the many other activities now available on college campuses, as well as the increasing amount of reading students must undertake in preparing papers, special projects, and independent study assignments. Some librarians apparently feel that unlike the teaching faculty, who have frequent personal contacts with students, there is not much, beyond providing attractive and conveniently located browsing collections and displays, that the library can do to affect student reading habits.

It was quite evident from the varied responses received that librarians themselves hold widely varying opinions on the subject of dormitory libraries. This brief presentation has attempted to touch upon these varying points of view. It would appear, on balance, that where concentrations of students, at some distance from the library, provide situations where residence hall libraries may fill a real need, such undertakings can contribute effectively to the total educational program, provided the library can devote the funding and leadership that is required. Whether residence hall li- 
braries should be developed on a given campus will depend on its own local situation with respect to the location and character of its student housing facilities and the interest and willingness of students, faculty, and the library administration to support and participate in such a program.

\section{Needed Research}

One element that requires more study and research than has yet appeared in literature involves the question, "What do students do, or want to do, in their free time?" If they are largely preoccupied with dates, bull sessions, ping pong, pool or billiards, sports and athletics, work for student organizations, practicing the guitar, listening to hi-fi, driving around, or attending dances, concerts, lectures, movies, and the theater, then possibly the hope of stimulating voluntary student reading through enriched residence hall libraries may be doomed to failure. If, on the other hand, there is evidence that on a given campus, resident students have substantial free time for such reading, and are not primarily engaged in a variety of other outside activities, then there may well be a rich opportunity for making residence hall libraries a significant element in their total campus educational experience.

\section{Guidelines for Planning}

Most of the librarians who have residence hall library programs in operation readily acknowledge the educational potential of such libraries as a supplement to what the main campus library can offer. Their responses suggest that to be effective such collections should include at least (1) a modest collection of reference tools, where factual information can be quickly located without having to make a trip to the central library; (2) a selection of at least a dozen general periodicals including news and commentary on contemporary affairs; (3) a generous representation of the most heavily used course-related books for assigned and collateral reading; (4) a modest but carefully selected collection of new books of recreational appeal; and (5) a few of the world's great popular classics in attractive editions. Collections made up primarily of complete sets of Victorian authors, however beautifully bound, or of surplus books not needed by the central library, should be avoided, however great may be the temptation to fill up the shelves with such material. Free or cast-off books are usually no more inviting than cast-off clothing. Books for residence hall libraries should be selected and purchased with their day-to-day use in mind, and collections should be regularly enriched with new titles and weeded at least annually to remove deadwood or they will wither on the vine. In short, to use an overworked cliché; one gets from residence hall libraries only what he is willing to put into them.

Probably an appropriate admonition to institutions considering the development of residence hall libraries is to analyze their local situation in terms of campus geography, library attitudes, student and faculty interest, the philosophy of its student personnel program, and-not the least-the cost of maintaining such libraries in relation to overall library support. Then, if the climate appears favorable, it should be urged that if such a program is undertaken, it be guaranteed sufficient financing and on-going advisory support from the library to assure that the educational potential envisioned for the project will be realized. 